\title{
СУЧАСНІ ПІДХОДИ ДО ВИРІШЕННЯ ПРОБЛЕМИ ПІДВИЩЕННЯ ЕНЕРГОЕФЕКТИВНОСТІ СУШІННЯ НАСІННСВОГО ЗЕРНА
}

В.М. Пазюк, д-р техн. наук, провідний науковий співробітник

Інститут технічної теплофізики НАН України,

02000, вул. Булаховського, 2, м. Київ, Україна.

В статті запропоновані сучасні методи низькотемпературного сушіння зернових культур. Найбільш поширені для сушіння зернових культур бункери та силоси для вентилювання, сушарки колонкового та шахтного типу. Приведені енергетичні витрати зерносушарок у найбільш відомих виробників, щьо становлять в залежності від типу зерносушарки 4350 - 5000 кДж/кг випареної вологи. Розроблена енергетична класифікація існуючих зерносушарок в залежності від заходів направлених на зниження енергетичних витратах теплоти, але иього недостатньо. Витрати теплоти в існуючих зерносушарках потрібно зменшувати, тому розроблені заходи із зниження витрат теплоти на процес сушіння, серед яких дочільно застосувати теплові насоси, які вирімують комплексно проблему енергоефективності.

Ефективність теплонасосної установки підтверджується проведеними експериментальними дослідженнями, в якій розраховані енергетичні витрати на 1 кг випареної вологи, щчо становлять 3675-3700 кДж/кг випареної вологи. Прочес сушіння насіння зернових культур в теплонасосній сушильній установці проходить періоди нагрівання, постійної та падаючої швидкості сушіння. Найбільш дочільна температура сушильного агента $50^{\circ} \mathrm{C}$, швидкість сушіння $1,5 \mathrm{~m} / \mathrm{c} \mathrm{ma} \mathrm{шар}$ матеріалу в 20 мм. Насіннєві властивості зернових культур після теплової обробки зберігаються на рівні 99-100\%.

Вирішення проблеми енергоефективності сушіння насіння зернових культур досягається встановленням в технологічну схему сушіння теплонасосної установки. Зерносушильна установка складається з 3-х зон, перша зона з температурою $80^{\circ} \mathrm{C}$ необхідна для швидкого підігрівання насіння зернових культур, друга зона із температурою теплоносія $50^{\circ} \mathrm{C}$ від конденсатора теплового насосу дозволяє сушити насіння, третя зона використовується для охолодження матеріалу від випарника теплового насосу. Бібл. 10, рис. 6.

Ключові слова: насіння, теплові насоси, сушіння, енергоефективність.

\section{MODERN APPROACHES TO THE SOLUTION OF THE PROBLEM OF INCREASING THE ENERGY EFFICIENCY OF SEED GRAIN DRYING}

\author{
V. Paziuk, doctor of technical science, leading researcher \\ Institute of Engineering Thermophysics of NAS of Ukraine, \\ 02000, street Bulakhovsky, 2, Kyiv, Ukraine.
}

The article offers modern methods of low-temperature drying of grain crops. The most common for drying grain crops are bunkers and silos for ventilation, column and mine type dryers. The energy costs of grain dryers at the most known manufacturers, which are depending on the type of grain dryer.

4350 - $5000 \mathrm{~kJ} / \mathrm{kg}$ of evaporated moisture. An energy classification of existing grain dryers has been developed depending on measures aimed at reducing energy heat consumption, but this is not enough. Heat consumption in existing grain dryers needs to be reduced, so measures have been developed to reduce heat consumption for the drying process, among which it is advisable to use heat pumps that comprehensively solve the problem of energy efficiency.

The efficiency of the heat pump installation is confirmed by the conducted experimental researches in which energy expenses on $1 \mathrm{~kg}$ of the evaporated moisture making 3675-3700 kJ / kg of the evaporated moisture are calculated. The process of drying cereal seeds in a heat pump drying unit undergoes periods of heating, constant and decreasing drying speed. The most suitable temperature of the drying agent is $50^{\circ} \mathrm{C}$, the drying speed is $1.5 \mathrm{~m} / \mathrm{s}$ and a layer of material of $20 \mathrm{~mm}$. Seed properties of grain crops after heat treatment remain at the level of $99-100 \%$.

The solution to the problem of energy efficiency of drying of seeds of grain crops is reached by installation in the technological scheme of drying of the heat pump installation. The grain drying unit consists of 3 zones, the first zone with a temperature of $80{ }^{\circ} \mathrm{C}$ is necessary for fast heating of seeds of grain crops, the second zone with a heat carrier temperature of $50^{\circ} \mathrm{C}$ from the condenser of the heat pump allows to dry seeds, the third zone is used for cooling of material from the heat pump evaporator. Ref. 10 , fig. 6.

Keywords: seeds, heat pumps, drying, energy efficiency.

(C) B.М. Пазюк, 2021

Відновлювана енергетика. 2021. № 4 


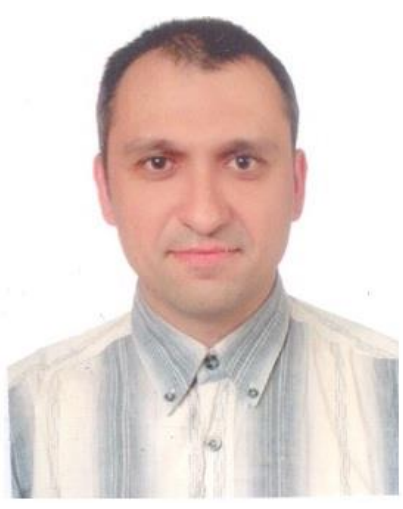

\section{В.М. Пазюк \\ V. Paziuk}

Відомості про автора: провідний науковий співробітник відділу тепломасопереносу в теплотехнологіях Інституту технічної теплофізики НАН України.

Освіта: доктор технічних наук зі спеціальності 05.14 .06 - технічна теплофізика та промислова теплоенергетика, Інституту технічної теплофізики НАН України.

Наукова сфера: сушіння зерна Публікації: 108

ORCID: 0000-0002-4955-1941

Контакти: тел.: +38(096)223-53-06

e-mail: vadim_pazuk@ukr.net
Author information: Leading researcher of the Department of Mass Transfer and Heat Technologies of the Institute of Engineering Thermophysics of the National Academy of Sciences of Ukraine.

Education: doctor of technical science in the specialty 05.14 .06 - technical thermal physics and industrial combined heat and power, Institute of Engineering Thermophysics of the National Academy of Sciences of Ukraine.

Research area: drying of grain

Publications: 108

ORCID: 0000-0002-4955-1941

Contacts: тел.: +38(096)223-53-06

e-mail: vadim_pazuk@ukr.net
3 метою запобігання великим витратам енергії необхідно збільшити енергоефективність процесу сушіння зерна. Розв'язанню цієї проблеми сприятиме запровадження комплексних рішень з енергоефективності, як-от:

- вдосконалення технології сушіння зерна (застосування оптимальних режимів сушіння, заходи 3 рециркуляції теплоносія та зерна, ефективне нагрівання й охолодження, застосування теплонасосних технологій для зневоднення теплоносія та інші технологічні рішення);

- автоматизація процесу (організація контролю вологості зерна, температури та швидкості руху теплоносія з виводом показників на дисплей щита керування або монітор комп'ютера);

- вдосконалення конструкцій зерносушарок, що забезпечують рівномірне нагрівання, сушіння й охолодження зерна (рівномірне розподілення теплоносія по перерізу шахти i по довжині коробів, безперервне завантаження та випуск зерна 3 регулюванням необхідної швидкості переміщення по сушарці);

- зниження втрат теплоти в навколишнє середовище (встановлення теплоізоляції зерносушарок, вдосконалення конструкції топкових пристроїв, правильна експлуатація зерносушильного обладнання).

Підвищення цін на енергоносії, підвищення вимог до охорони довкілля вимагають нового підходу до енергозабезпечення виробництва сушіння зерна шляхом впровадження сучасних енергоощадних технологій. Одним із напрямів енергоефективного способу сушіння зерна $\epsilon$ використання теплонасосних технологій.

Проведений аналіз сушильних технологій показав, що основними проблемами при сушінні зерна, що потребують вирішення, є зменшення енергетичних витрат і шкідливих викидів в атмосферу, безпечність продукту.

Для сушіння зерна насіннєвого призначення здебільшого використовують безперервно діючі зерносушарки шахтного й колонкового типів. Використання зерносушарок барабанного, карусельного та інших типів обмежено вимогами до якості насіннєвого матеріалу. Також сушіння насіння можливо в сушарках періодичної дії - порційних, камерних, у бункерах для вентилювання (рис. 1)

В бункерах для вентилювання насіння сушать зовнішнім або злегка підігрітим повітрям; це низькотемпературне сушіння, що грунтується на принципі гігроскопічної рівноваги між 
вологістю матеріалу та повітря. Вентилювати зерно 3 метою сушіння можливо тоді, коли відносна вологість повітря обумовлює поглинання випареної вологи.

Для досягнення кондиційної вологи зерна відносна вологість повітря в умовах гігроскопічної рівноваги повинна складати 65$70 \%$. Підігрів повітря на $1{ }^{\circ} \mathrm{C}$ знижує його відносну вологість на 4-5\%.

В умовах Англії для висушування зерна до кондиційної вологи рекомендують підігрівати повітря в холодну вологу погоду до $4,5-5,5^{\circ} \mathrm{C}$; у прохолодну - до $3,5-4,5^{\circ} \mathrm{C}$ і в теплу суху - до $3,5^{\circ} \mathrm{C}$. Питома витрата повітря повинна складати 200-300 м³/(т · год) [1].

Для низькотемпературного сушіння зерна здебільшого використовують вентильований бункер циліндричної форми з вертикальнім або радіальним повітряним потоком i силос для вентилювання зерна [2] (рис. 1, $a$ ).

Переваги низькотемпературного сушіння такі: невеликі витрати теплоти - на рівні 3000 кДж/кг випареної вологи; рівномірність висушеного матеріалу за вологістю; простота технічних засобів для виготовлення сушарки.
Недоліком низькотемпературного сушіння $\epsilon$ те, що процес вологовіддачі триває декілька діб, що пов'язано з ризиком псування матеріалу.

Для високотемпературного сушіння зерна можна використовувати більшість конструкцій вентиляційних установок (закройні, напільні тощо), в робочій камері яких зерно розташовується нерухомим щільним шаром. Проте режими сушіння будуть іншими: товщина зернового шару - 0,4-0,6 м; питома витрата повітря $\quad 500-1500 \quad \mathrm{~m}^{3} /(\mathrm{T} \cdot$ год) зерна; повітря нагрівають до температури $35-60{ }^{\circ} \mathrm{C}$ (залежно від вологості та призначення насіння) [3].

Сушарки фірми Gilmore \& Tatge Mfg., CO (США) мають циліндричну форму, в нижній частині - конусоподібну (рис. 1, б) [4].

Сушильна камера виготовлена 3 оцинкованої сталі, має круглі отвори діаметром 2,4 мм, перфорація складає $33 \%$ всієї площі стінок. Насіння перебуває між перфорованими зовнішніми стінками і стінками нагнітальної камери. Циркуляція насіння відбувається за допомогою вертикального центрального шнеку. При розвантаженні сушарки насіння подається у розвантажувальну трубу. 

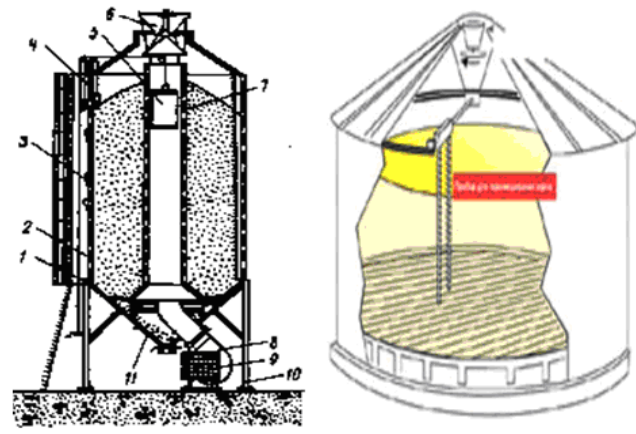

$a$
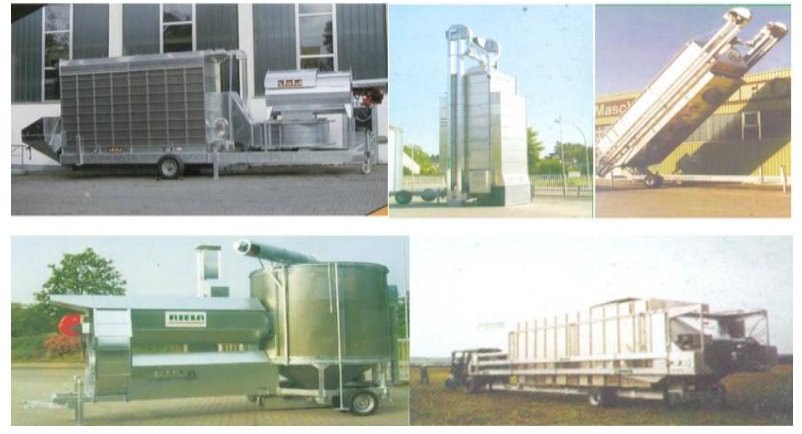

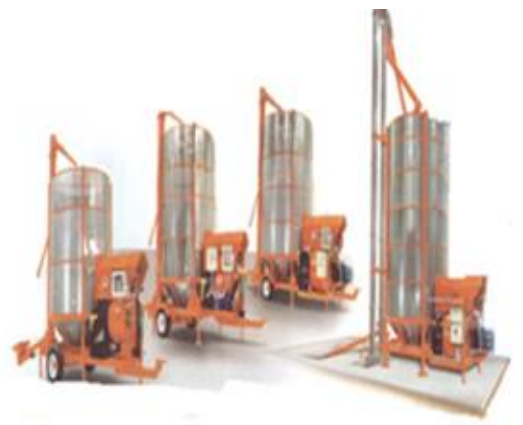

$\sigma$
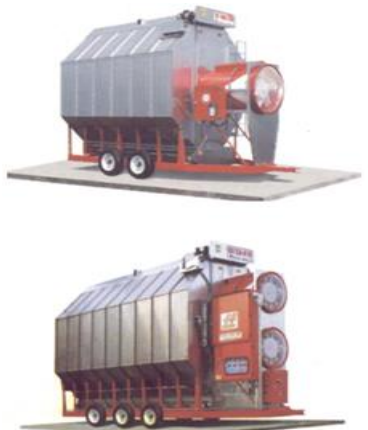

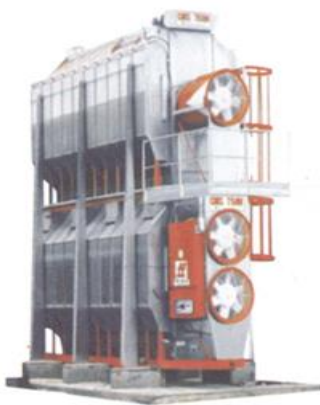

Рис. 1. Сучасне обладнання для сушіння насіння зернових культур:

$a$ - бункер та силос для вентилювання; $\sigma$ - сушарка періодичної дії фірми Gilmore $\&$ Tatge Mfg.,СО (США); в - порційні та прямоточні зерносушарки фірм Stela (Німеччина), Riela (Німеччина); г - колонкові зерносушарки фірми Farm Fans (США)

Fig. 1. Modern equipment for drying grain seeds:

a - bunker and silo for ventilation; b - dryer of periodic action of Gilmore \& Tatge Mfg., CO (USA); in - portion and direct-flow grain dryers of Stela (Germany), Riela (Germany) firms; g - column grain dryers of Farm Fans firm (USA)

Пересувні порційні та прямоточні Company, Delux, Sukup, Farm Fans (рис 1, г) та зерносушарки фірми Stela та Riela (Німеччина) інші [7-10].

випускаються різної продуктивності та конструктивного виконання (рис. 1, в), [5,6].

Переваги: сушіння зерна безпосередньо в польових умовах; зниження витрат на транспортування зерна.

Недоліки: партії зерна повинні мати однакову початкову вологість; для запобігання перегрівання та погіршення якості зерна його вологість у прямоточних сушарках знижують не більш ніж на $6 . . .8 \%$.

Найвідоміші виробники колонкових зерносушарок - американські фірми Mathews
У цих сушарках зерно під дією сили тяжіння рухається зверху вниз між двома перфорованими стінками, які підлягають впливу теплоносія у повздовжньому напрямку. Колонкові сушарки забезпечують більш високу питому подачу теплоносія (без виносу зерна), ніж шахтні. Завдяки вільному руху зерна в колонках знижується можливість утворення застійних зон.

На рис. 2 представлені питомі витрати теплоти в існуючих зерносушарках, серед наведених сушарок економічними $є$ колонкові зерносушарки. 


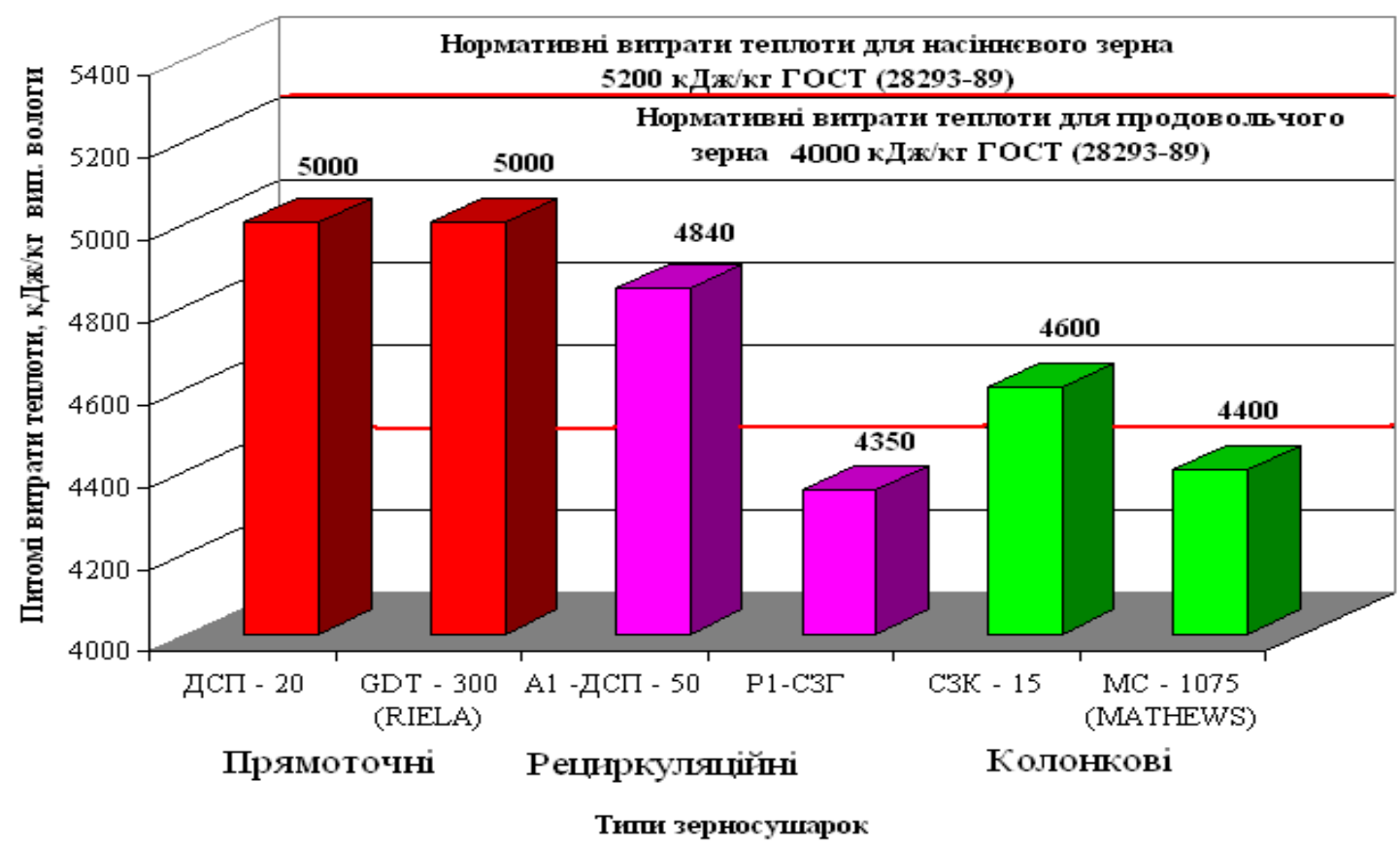

Рис. 2. Питомі витрати теплоти в існуючих типах зерносушарок

Fig. 2. Specific heat consumption in existing types of grain dryers

Відповідно до здійснюваних заходів, спрямованих на зниження питомих витрат теплоти на сушіння зерна, зерносушарки можна поділити на чотири групи [10]:

1. Зерносушарки, в яких не застосовують утилізації охолоджувального повітря. Питомі витрати теплоти становлять 5000 кДж/кг вип. вологи, при коефіцієнті корисної дії (КДД) 49,2\% .

\section{2. Установки} 3 охолоджувального повітря i частково відпрацьованого ненасиченого теплоносія 3 нижніх зон сушіння. Утилізація охолоджувального повітря знижує питомі витрати теплоти до 4800 кДж/кг вип. вологи. КДД збільшується до 52,4 \%.
3. Сушарки, що використовують утилізацію охолоджувального повітря і ненасиченого теплоносія. Питомі витрати теплоти становлять 4350-4400 кДж/кг вип. вологи, ККД - 56,9\%.

4. Сушарки, що використовують утилізацію охолоджувального повітря, ненасиченого і насиченого теплоносія. Питомі витрати теплоти досягають 3800 кДж/кг вип. вологи з ККД 77,5 \% .

На основі проведених за даними літератури досліджень розроблено енергоефективні схеми роботи існуючих зерносушарок (рис. 3). 


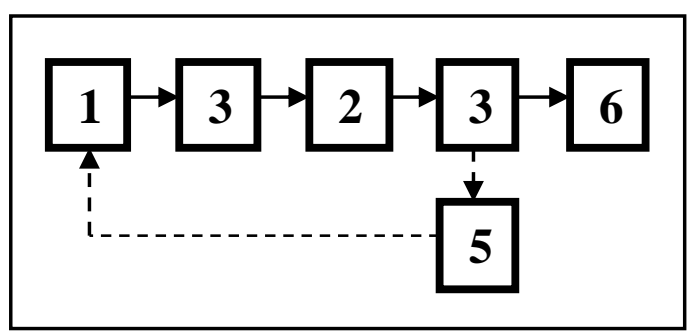

1-й спосіб ( РД-2х25-70,У2-УЗБ-50)

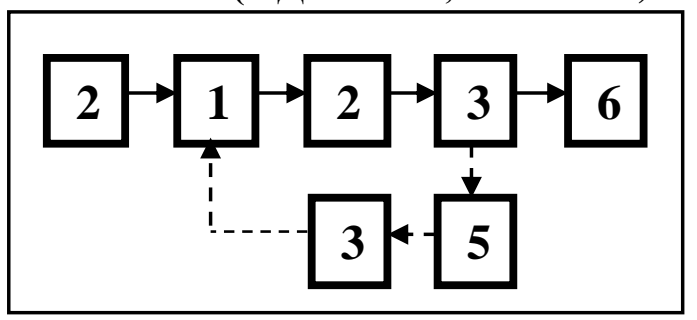

3-й спосіб (Цілинна-36)

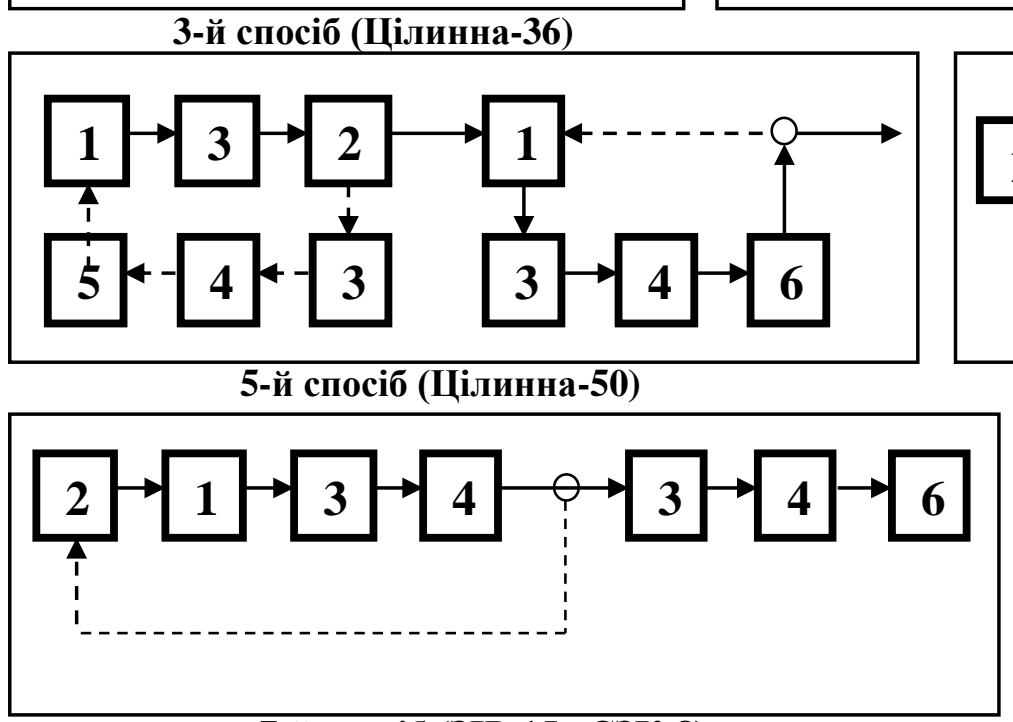

7-й спосіб (3IP-15, СЗК-8)

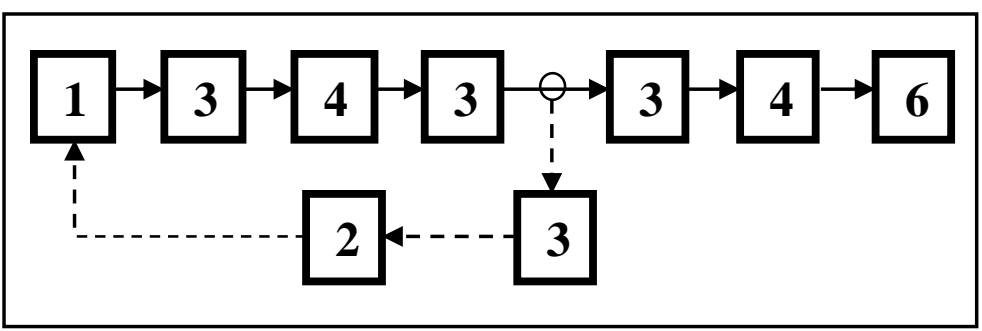

2-й спосіб (АІ-УЗМ, УІ-УСШ)

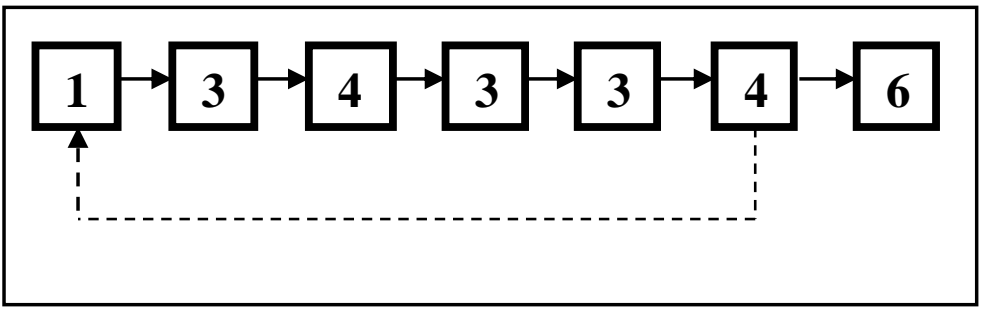

4-й спосіб (АІ-ДСП-50)

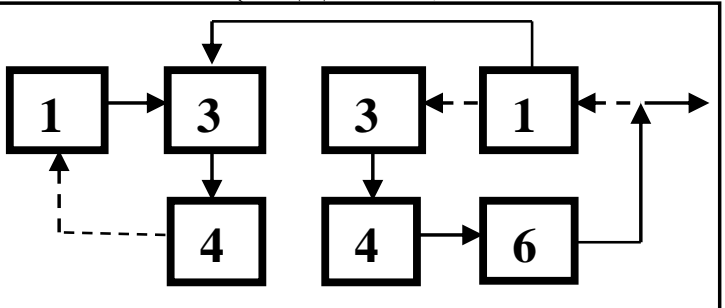

6-й спосіб (ДСП-25)

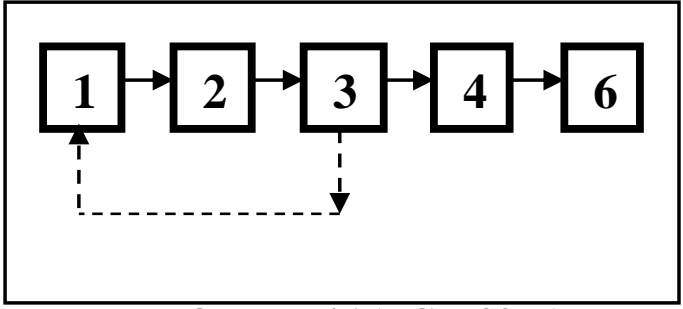

8-й спосіб (ДСП-32от)

Рис. 3. Технологічні режими сушіння насіння зернових культур у зерносушарках шахтного типу:

1 - змішування зерна різної вологості; 2 - короткочасне нагрівання в киплячому або падаючому шарі; 3 - відлежування багатокомпонентної суміші; 4 - сушіння зерна у гравітаційно-рухомому щільному шарі; 5- проміжне охолодження 3 одночасним зниженням вологості зерна; 6 - кінцеве охолодження просушеного зерна.

Fig. 3. Technological modes of drying of seeds of grain crops in grain dryers of mine type

1 - mixing of grain of different humidity; 2 - short-term heating in a fluidized or falling layer; 3 - aging of the multicomponent mixture; 4 - drying of grain in a gravitational-mobile dense layer; 5-intermediate cooling with simultaneous decrease in grain moisture; 6 - final cooling of the dried grain.

В представлених схемах як засіб системах опалення будинків, розглядається інтенсифікації здебільшого використовується також застосування низькопотенційної теплоти 3 змішування зерна різної вологості, рециркуляція конденсатора теплового насоса для сушіння та однократне $\quad$ або $\quad$ багатократне зернових культур насіннєвого призначення. відлежування насіння.

В Інституті технічної теплофізики НАН

Останніми роками особлива увага України розроблена теплонасосна зерносушильна приділяється теплонасосним технологіям у установка (рис. 4). 


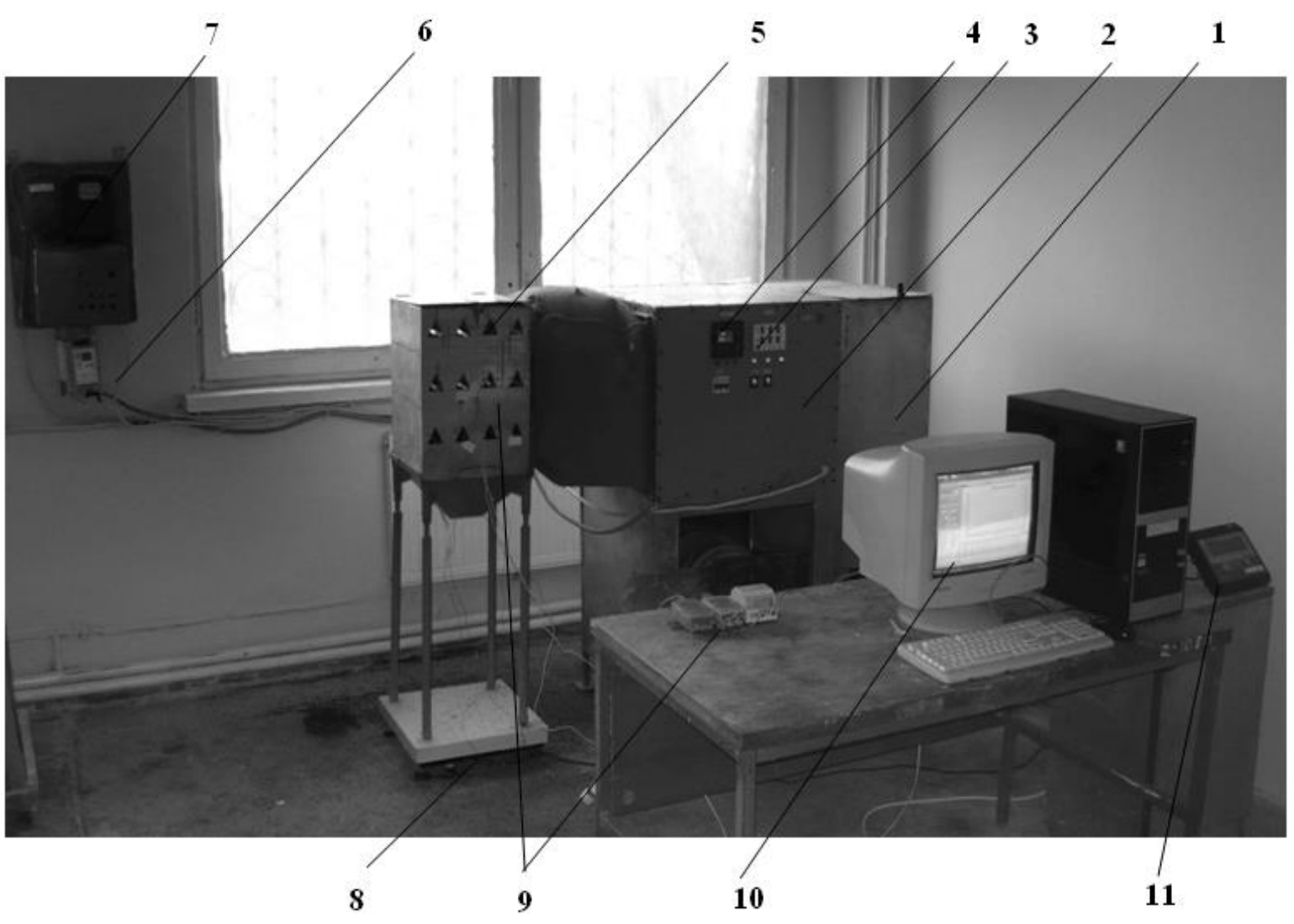

Рис. 4. Експериментальна теплонасосна зерносушарка:

1 - теплонасосний агрегат; 2 - щит керування; 3 - реле часу; 4 - термореле; 5 - сушильна шахта; 6 - регулятор швидкості; 7 - лічильник електроенергії; 8 - підлогові терези; 9 - аналого-цифровий перетворювач $i$-7018, конвертер інтерфейсу $i$-7520 та хромель-копелеві термоелектричні перетворювачі; 10 - персональний комп’ютер; 11 - цифрове табло терезів

Fig. 4. Experimental heat pump grain dryer:

1 - heat pump unit; 2 - control panel; 3 - time relay; 4 - thermal relay; 5 - drying mine; 6 - speed regulator; 7 - electricity meter; 8 - floor scales; 9 - analog-to-digital converter i-7018, interface converter i-7520 and chromel-kopel thermoelectric converters; 10 - personal computer; 11 - digital display of scales.

\section{Для дослідження та відпрацювання} технологічного режиму сушіння насіннєвого зерна виготовлений експериментальний зразок теплонасосної сушарки періодичної дії (рис. 4), обладнаний контрольно-вимірювальними приладами та системою автоматики, які дають змогу автоматично підтримувати заданий режим зневоднення, вимірювати та фіксувати необхідні параметри робочого процесу (температуру, вологовміст і швидкість руху теплоносія, витрати енергії та зменшення маси зерна), а також температуру і тиск випаровування та конденсації холодоагенту. Розроблена програма Cooler дозволяє автоматично знімати інформацію про зміну маси та температури шару насіння зернових культур в процесі видалення вологи.

Питомі витрати енергії під час сушіння на одиницю вилучення вологи визначаються за показником лічильника електроенергії та маси матеріалу на табло терезів.

Кінетика процесу сушіння й температурні криві сушіння насіння вівса, пшениці та ячменю представлена на рис. 5. 


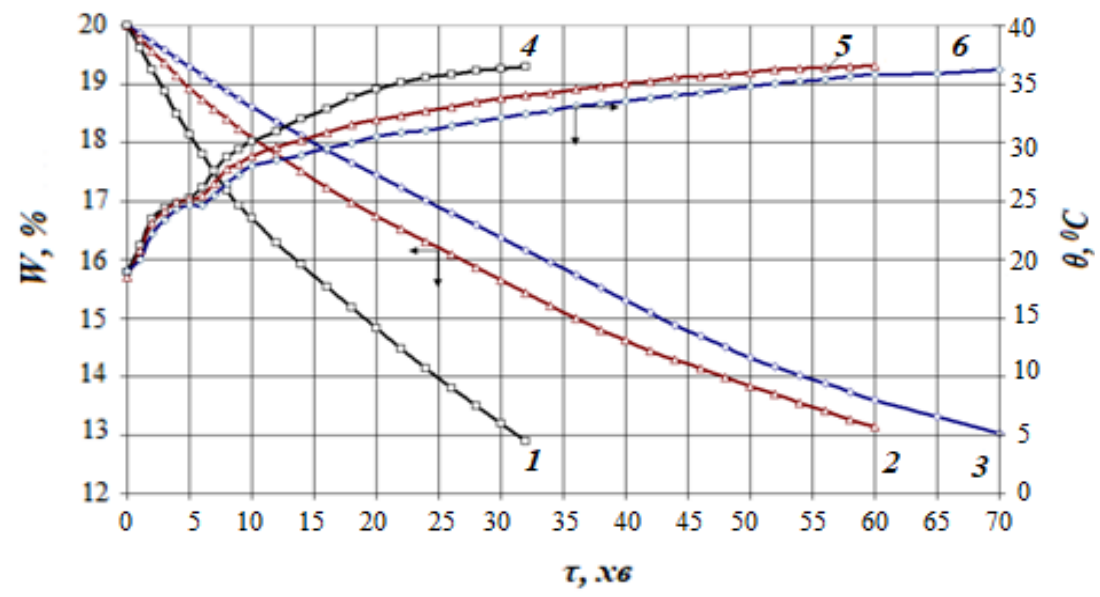

a)

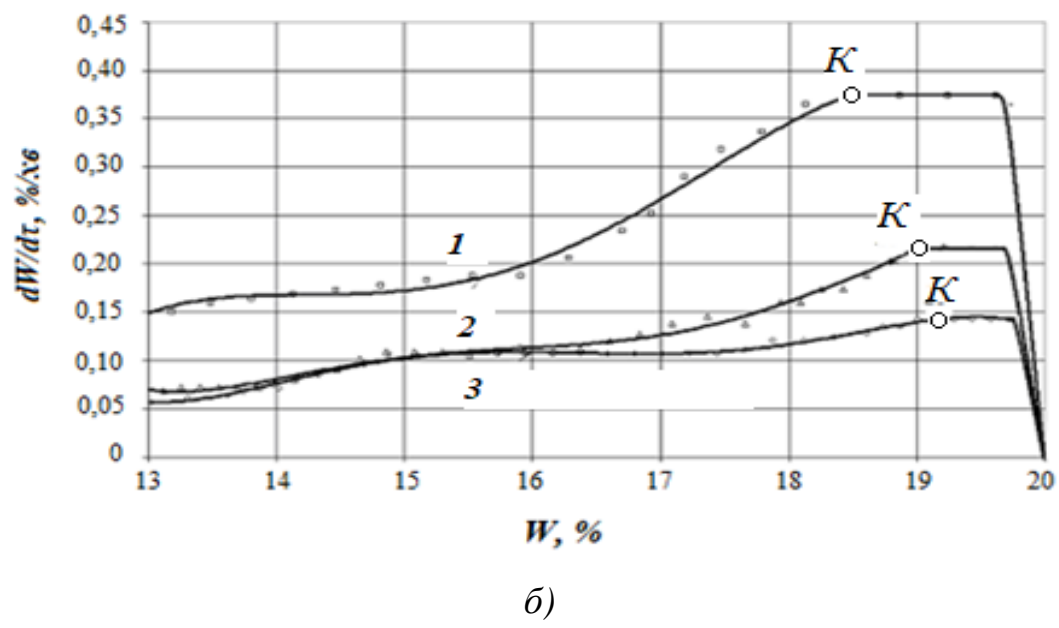

Рис. 5. Вплив температури теплоносія та температури нагрівання матеріалу на тривалість сушіння (a) та швидкість сушіння (б) насіння зернових культур $t=50^{\circ} \mathrm{C}, V=1,5 \mathrm{~m} / \mathrm{c}, S=20$ мм, $d=6$ г/кг с. п.:

1,4 - овес; 2,5- пшениця; 3,6 - ячмінь

Fig. 5. Influence of coolant temperature and material heating temperature on drying duration (a) and drying speed (b) of grain seeds $t=50^{\circ} \mathrm{C}, V=1,5 \mathrm{~m} / \mathrm{s}, S=20 \mathrm{~mm}, d=6 \mathrm{~g} / \mathrm{kg} \mathrm{d}$. a.:

1,4 - oats; 2.5 - wheat; 3.6 - barley

Із перелічених зернових культур найбільша інтенсивність спостерігається при сушінні насіння вівса. Тривалість сушіння насіння вівса від початкової вологості $20 \%$ до кінцевої вологості $13 \%$ становить 32 хв., що у 1,8 раза менше за пшениці та у 2,18 раза менше за тривалість сушіння ячменю. Насіння зернових культур прогрівається до температури $36-36,5^{\circ} \mathrm{C}$ (рис. 5,a).

Сушіння насіння зернових культур проходить періоди прогрівання, постійної та падаючої швидкості сушіння. Максимальна швидкість сушіння вівса складає 0,375\%/хв., пшениці - 0,218\%/хв, ячменю - 0,142\%/хв. (рис. 5, б)

Питома витрата теплоти на процес сушіння зернових культур у зерносушарці 3 тепловим насосом при температурі теплоносія $50{ }^{\circ} \mathrm{C}$ становить 3675-3700 кДж/кг вип. вологи. Насіннєві властивості зернових культур зберігаються на рівні 99-100 \%.

На основі експериментальних даних надані рекомендації зі встановлення теплового насосу в схему сушіння зернових культур (рис. 6). 


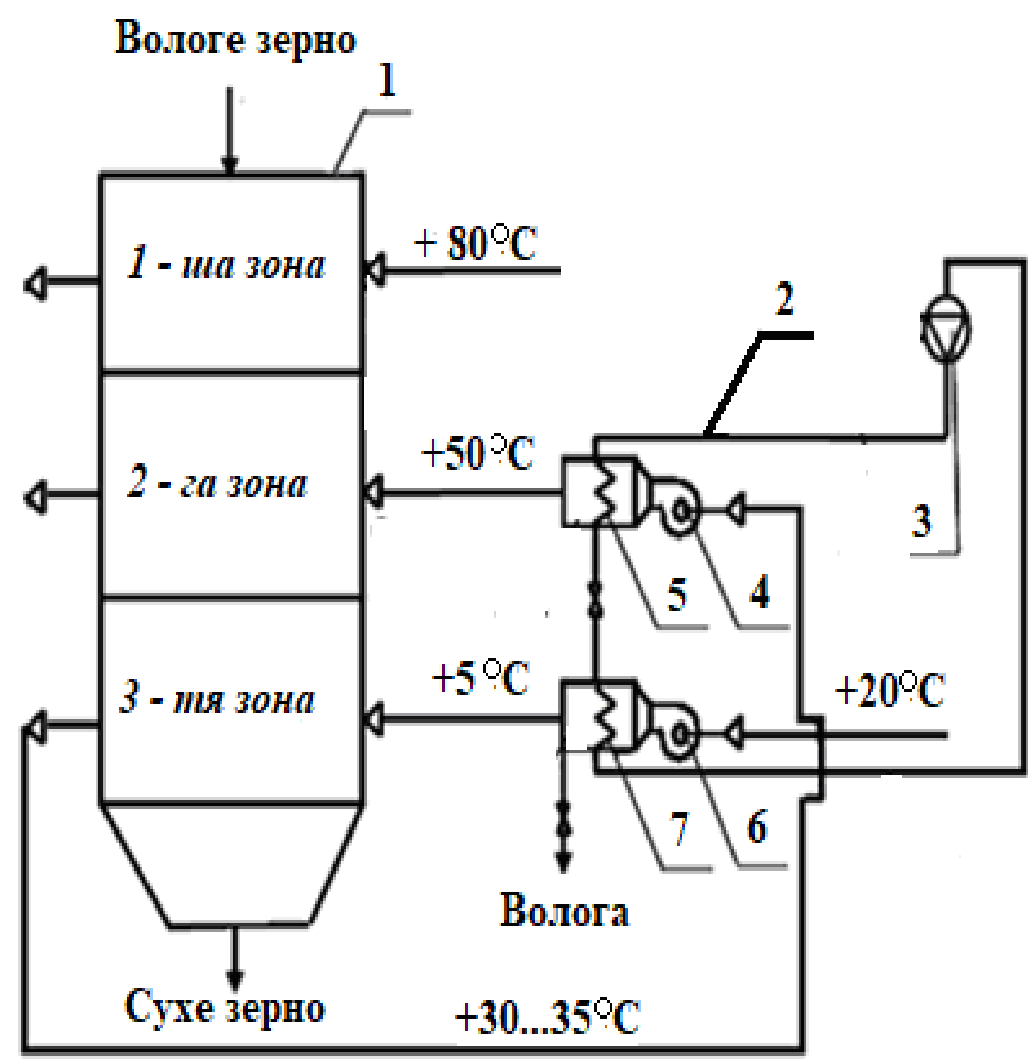

Рис. 6. Теплотехнічна схема низькотемпературного сушіння зернових культур:

1 - зерносушильна шахта; 2 - тепловий насос; 3 - компресор; 4, 6 - вентилятори; 5 - конденсатор; 7 - випарник.

Fig. 6. Heat engineering scheme of low-temperature drying of grain crops:

1 - grain drying mine; 2 - heat pump; 3 - compressor; 4, 6 - fans; 5 - capacitor; 7 - evaporator.

Шахтна зерносушарка складається 3 тризонної зерносушильної шахти (1) і теплового насоса (2), що складається 3 компресора (3), конденсатора

(5), випарника та терморегулювального вентиля. В першій зоні відбувається нагрівання та сушіння зернових культур при температурі теплоносія $80^{\circ} \mathrm{C}$ від газового теплогенератора. В другій зоні відбувається сушіння зерна при температурі теплоносія $50{ }^{\circ} \mathrm{C}$. Нагрівання теплоносія проходить на конденсаторі (5) теплового насоса (2) i вентилятором (4) направляється в зерносушильну шахту. В третій зоні висушене зерно охолоджується від випарника (7) теплового насоса (2) при температурі повітря $5{ }^{\circ} \mathrm{C}$. Ефективність охолодження забезпечується зниженням температури повітря від 20 до $5{ }^{\circ} \mathrm{C}$. 2-ї зон викидається в атмосферу, а з 3-ї зони відпрацьований теплоносій 3 температурою $30 \ldots 35{ }^{\circ} \mathrm{C}$ направляється на конденсатор (5) теплового насоса (2).

Висновки. 1. Проведений аналіз існуючих технологій сушіння зерна показав, що на процес сушіння витрачається велика кількість енергії. Серед наведених рекомендацій щодо зменшення витрат теплоти особлива увага приділяється насосним технологіям.

2. Результати досліджень показали можливість сушіння насіння зернових культур при низьких температурах 3 невисокими енерговитратами, що становлять 3675-3700 кДж/кг випареної вологи, що нижче на 30-40 \% порівняно з існуючими сушарками. 
3. Низькотемпературне сушіння насіннєвих культур у сушарці 3 тепловим насосом дає змогу зберегти насіннєві властивості зернових культур на рівні 99-100\%.

4. Розроблена теплотехнічна схема дозволяє інтенсифікувати низькотемпературне сушіння та ефективне охолодження насіння зернових культур за рахунок короткочасного нагріву при температурі $80^{\circ} \mathrm{C}$ та роботи теплового насоса.

1. Зерносушарки фірми Mathews Company. [Електронний ресурc]. URL: www.mathewscompany.com

2. Нагорский И., Карташевич С., Тимошек А. Повышение эффективности сушки зерна. Комбикормовая промышленность. 1998. № 1. С. 16.

3. Чижиков А.Г., Окунь Г.К. Оборудование для сушки зерна. Комбикормовая промышленность. 1996. № 2. C. 12-14.

4 Каталог продукції заводу Брянсельмаш. [Електронний ресурс].

URL: www agrobiznes.ru/agro/agroprod

5. Каталог продукції фірми Mela. [Електронний pecypc]. URL: www. mela.com.ua.

6. Каталог продукції фірми $\mathrm{Ag}$ - Progect. [Електронний ресурc]. URL: www.ag-projects.com.

7. Каталог продукції фірми Mерu. [Електронний ресурc]. URL: www. mepu.com.ua.

8. Каталог продукції фірми АО "Зерномонтаж". [Електронний ресурс].

URL: www.volgograd.ru/catalog/zernomontazh.org

9. Каталог продукції фірми QED - Мельинвест. [Електронний ресурc]. URL: www.melinvest.ru.

10. Сорочинський В. Зневоднення зерна за різних схем утилізації сушильного агента й охолоджуючого повітря може бути доволі ефективно. Зерно і хліб. 2011. № 3. С. 40-41.

\section{REFERENCES}

1. Zernosusharky firmy Mathews Company. [Grain dryers of Mathews Company]. [Electronic resource].

URL: www.mathewscompany.com [in Ukrainian].

2. Nagorsky I., Kartashevich S., Timoshek A. Povysheniye effektivnosti sushki zerna. [Improving the efficiency of grain drying]. Kombikormovaya promyshlennost. 1998. No.1. 16 p. [in Russian].

3. Chizhikov A.G., Okun G.K. Oborudovanye dlya sushky zerna. [Grain drying equipment]. Kombikormovaya promyshlennost. 1996. No. 2. Pp. 12-14. [in Russian].

4. Kataloh produktsiyi zavodu Bryanselmash. [Product catalog of the Bryanselmash plant]. [Electronic resource].

URL: www agrobiznes.ru/agro/agroprod. [in Ukrainian]

5. Kataloh produktsiyi firmy Mela. [Product catalog of Mela]. [Electronic resource]. URL: www. mela.com.ua. [in Ukrainian].

6. Kataloh produktsiyi firmy Ag-Project. [Ag-Project product catalog]. [Electronic resource]. URL: www.ag-projects.com [in Ukrainian].

7. Kataloh produktsiyi firmy Mepu. [Catalog of Mepu products]. [Electronic resource]. URL: www. mepu.com.ua. [in Ukrainian].

8. Kataloh produktsiyi firmy AO "Zernomontazh". [Catalog of products of $\mathrm{AO}$ "Zernomontazh"]. [Electronic resource]. URL: www.volgograd.ru/catalog/zernomontazh.org [in Ukrainian].

9. Kataloh produktsiyi firmy QED - Mel'ynvest. [QEDMelinvest product catalog]. [Electronic resource]

URL: www.melinvest.ru. [in Ukrainian].

10. Sorochynskyy V. Znevodnennya zerna za riznykh skhem utylizatsiyi sushyl'noho ahenta y okholodzhuyuchoho povitrya mozhe buty dovoli efektyvno. [Dehydration of grain under various schemes of utilization of drying agent and cooling air can be quite effective]. Zerno i khlib. 2011. No 3. Pp. 40-41. [in Ukrainian]. 